\title{
ANALISA KONTRIBUSI PROGRAM KAMPUNG KB DALAM UPAYA PENINGKATAN PROGRAM KKBPK DI KAB. JOMBANG, PROVINSI JAWA TIMUR
}

\section{Analysis Of Contribution Of KB Kampung Program In Efforts To Improve the KKBPK Program In Jombang, East Java Province}

\author{
Agus Raikhani $^{1}$, Novy Setia Yunas $^{2}$, Linda Ratnasari ${ }^{3}$, Iswari Hariastuti ${ }^{4}$ \\ 1,2,3 Universitas Darul 'Ulum Jombang \\ E-mail: agusraikhani@gmail.com \\ ${ }^{4}$ Peneliti BKKBN Perwakilan Provinsi Jawa Timur \\ E-mail: iswarihariastuti@yahoo.com
}

\begin{abstract}
ABSTRAK
Arah pembangunan dewasa ini tentunya tidak semata mengarah pada pembangunan fisik semata, melainkan lebih dari itu pembangunan manusia secara menyeluruh. Mulai dari aspek ekonomi, pendidikan, perkembangan teknologi, peningkatan akses kesehatan, peningkatan dalam infrastruktur yang tersedia dan peningkatan dalam pendapatan serta kemakmuran masyarakat. Sesuai dengan amanat UU 52/2009, maka salah satu wujud konkrit dalam pembangunan manusia adalah melalui Pembentukan Kampung KB. Program kampung KB merupakan salah satu program pemerintah dalam agenda prioritas pembangunan Nawacita sebagai bagian dari penguatan program KKBPK. Tulisan ini akan menjelaskan kontribusi Kampung KB sejak dicanangkan tahun 2016 di Kabupaten Jombang dalam upaya peningkatan program KKBPK yang didalamnya terdapat beberapa indikator antara lain peningkatan jumlah akseptor $\mathrm{KB}$ baru, terlayaninya kesehatan ibu hamil dan menyusui, remaja aktif dalam kegiatan BKR dan PIK, penurunan angka buta aksara, meningkatnya partisipasi keluarga pra sejahtera dan KS-1 dalam program UPPKS. Metode yang digunakan melalui pendekatan deskriptif kualitatif dengan metode eksplorasi pada 3 wilayah Kampung KB yang tersebar di Kabupaten Jombang. Hasilnya, secara umum keberadaan Kampung KB berkontribusi secara signifikan pada penguatan program KKBPK, namun kontribusi tersebut dirasa belum maksimal mengingat masih kuatnya ego sektoral diantara stakeholder terkait program maupun anggaran, sehingga dibutuhkan political will dan model sinergitas antar stakeholder yang ada tersebut. Selain itu, perencanaan yang partisipatif dari masyarakat dan pemberdayaan potensi yang ada menjadi salah satu kunci keberhasilan program Kampung KB.
\end{abstract}

Kata Kunci: pembangunan, keluarga, kependudukan, kampung kb

\begin{abstract}
The development is certainly not merely directed at physical development, but more than that of human development as a whole. Starting from the aspects of economics, education, technological development, increasing access to health, improvements in available infrastructure and an increase in income and prosperity. In accordance with the mandate of Law 52/2009, then one of the concrete manifestations in human development is through the Establishment of Kampung KB. Kampung KB program is one of the government's programs in the Nawacita development priority agenda as part of strengthening the KKBPK program. This paper will explain the contribution of Kampung KB since it was launched in 2016 in Jombang Regency in an effort to improve KKBPK programs in which there are several indicators including increasing the number of new KB acceptors, serving the health of pregnant and lactating mothers, active adolescents in BKR and PIK-R activities, decreasing blind numbers characters, increased participation of pre-prosperous families and KS-1 in the UPPKS program. The method used is a qualitative descriptive approach with exploration methods in 3 areas of Kampung $K B$ scattered in Jombang Regency. As a result, in general the existence of Kampung $K B$ contributed significantly to the strengthening of the KKBPK program, but the contribution was deemed not optimal given the still strong sectoral ego among stakeholders related to the program and budget, so that political will and synergy models among existing stakeholders were needed. In addition, participatory planning from the community and empowerment of existing potentials are one of the keys to the success of the Kampung $K B$ program.
\end{abstract}

Keyword: Development, Family, Population, Kampung KB 


\section{PENDAHULUAN}

Pembangunan menjadi kunci menuju kesejahteraan masyarakat. Pemerintah dituntut untuk bisa mempercepat pembangunan demi kesejahteraan masyarakatnya (Yunita, 2016). Pemerintah sebagai regulator dan eksekutor kebijakan bertanggungjawab penuh untuk meningkatkan kesejahteraan masyarakat, menjunjung tinggi keinginan rakyat, melaksanakan pembangunan berkelanjutan, dan berkeadilan sosial, menjalankan aspek-aspek fungsional dari pemerintahan secara efisien dan efektif.

Penduduk merupakan modal dasar dalam mewujudkan pembangunan berkelanjutan. Pembangunan yang baik hanya akan bisa diwujudkan oleh penduduk yang berkualitas baik, yang tentu tergantung pada besar jumlah penduduk. Jumlah penduduk yang besar dengan laju pertumbuhan yang cepat serta kualitas rendah tentu mempersulit tercapainya tujuan pembangunan dan menimbulkan masalah peningkatan jumlah penduduk. Permasalahan peningkatan jumlah penduduk merupakan permasalahan penting yang dialami oleh banyak Negara berkembang, termasuk Indonesia. Besarnya jumlah dan laju pertumbuhan penduduk yang tidak diimbangi dengan kondisi kesejahteraan yang baik masih menjadi permasalahan pokok di Indonesia (Zultha, 2017). Berdasarkan data Badan Pusat Statistik (BPS), sensus penduduk tahun 2010, menunjukan bahwa jumlah penduduk di Indonesia telah mencapai 255.461.700 jiwa dengan jumlah laki-laki sebanyak 128.648.542 jiwa dan jumlah perempuan sebanyak 126.813.158 jiwa. Jumlah penduduk di Indonesia masih akan terus meningkat setiap tahunnya (BPS, 2010).

Menyikapi permasalahan peningkatan jumlah penduduk, pemerintah Indonesia kemudian fokus menjalankan program Keluarga Berencana (KB). Program KB di Indonesia dimulai sejak masa Orde Baru (1971) dan pernah terbukti mampu menekan laju pertumbuhan penduduk di Indonesia. Berdasarkan BPS, laju pertumbuhan penduduk pada tahun 1971-1980 adalah $2,31 \%$. Jika dilihat dalam sepuluh tahun berikutnya, angka ini mengalami penurunan yang cukup signifikan, yakni sebesar $1,47 \%$ pada tahun (1990-2000). Jumlah penduduk
Indonesia pada tahun 2010 kurang lebih mencapai 237.556.363 jiwa dengan laju pertumbuhan penduduk mencapai $1,49 \%$. Artinya, ada penambahan sekitar 3,5 hingga 4 juta penduduk setiap tahun. Dengan pertumbuhan sebesar ini, jumlah penduduk Indonesia diakhir tahun 2015 diperkirakan akan menyentuh 250 juta jiwa. Akan tetapi, dalam sepuluh tahun terakhir (2000-2010) laju pertumbuhan penduduk Indonesia kembali naik dan ini tentu menjadi perhatian penting bagi pemerintah agar lebih serius dalam menjalankan program KB (BKKBN, 2014). Khusus di Provinsi Jawa Timur, selama tiga dasawarsa terakhir ini jumlah penduduk Jawa Timur terus meningkat pesat meski laju pertumbuhan penduduk menunjukkan kecenderungan menurun. Data Sensus Penduduk tahun 2000 dari Badan Pusat Statistik (BPS, 2000) sebesar 34.765.998 jiwa, terjadi kenaikan dalam sepuluh tahun hasil Sensus penduduk tahun 2010 sebesar 37.476.011 jiwa (BPS,2010). Data hasil sensus menunjukkan setiap sepuluh tahun terjadi kenaikan kurang lebih 3 juta jiwa. Jika dihitung sejak tahun 1961 terjadi kenaikan kurang lebih 16 juta (BPS, 2010).

Jumlah penduduk Indonesia saat ini melaju dengan cepat dan mengakibatkan angka pengangguran dan kemiskinan semakin tinggi. Pada dasarnya hasil dari program KB berguna untuk pembangunan dan perkembangan masyarakat Indonesia itu sendiri. Upaya untuk terus memaksimalkan pelaksanaan program KB tentu menjadi pilihan mutlak bagi pemerintah saat ini. Pelaksanaan program KB Nasional dimandatkan kepada Badan Kependudukan Keluarga Berencana Nasional sebagai sebuah lembaga non kementerian. BKKBN merupakan lembaga resmi pelaksana teknis program yang pelaksana kegiatannya terstruktur secara hierarkis dan terkoordinasi mulai dari tingkat pusat, provinsi, kabupaten/kota, hingga Petugas Lapangan Keluarga Berencana (PLKB) yang berada di kecamatan dan kelurahan/desa (Zultha, 2017). Sesuai Undang-undang nomor 52 tahun 2009 tentang perkembangan kependudukan dan pembangunan keluarga sebagai dasar pelaksanaan program Kependudukan Keluarga Berencana dan Pembangunan Keluarga atau yang disingkat dengan KKBPK 
(BKKBN,2016). Salah satu pengejawantahan Undang- undang tersebut khususnya dalam pembangunan keluarga melalui Pembentukan Kampung KB yang merupakan penguatan program Kependudukan Keluarga Berencana dan Pembangunan Keluarga (KKBPK) yang dilakukan dengan menyusun kegiatan dengan memperkuat pencapaian target/sasaran secara langsung bersentuhan dan memberikan manfaat kepada masyarakat.

Pembentukan Kampung KB diharapkan menjadi salah satu inovasi strategis untuk dapat mengimplementasikan kegiatankegiatan prioritas program KKBPK secara utuh di lini lapangan dalam mewujudkan Agenda Prioritas 5 (lima) dari 9 agenda prioritas pemerintahan periode 2015 - 2019 yakni "Meningkatkan Kualitas Hidup Manusia Indonesia" melalui Pembangunan Kependudukan dan Keluarga Berencana. Apalagi BKKBN sendiri telah menyusun Renstra 2015 - 2019 dengan 6 (enam) sasaran strategis yang telah ditetapkan, yaitu: (1) menurunkan rata-rata Laju Pertumbuhan Penduduk (LPP) dari 1,38\% per tahun pada tahun 2015 menjadi $1,21 \%$ per tahun di tahun 2019, (2) menurunnya Total Fertility Rate (TFR) dari 2,37 per Wanita Usia Subur (WUS) di tahun 2015 menjadi 2,28 di tahun 2019, (3) meningkatnya Contraceptiive Prevalence Rate (CPR) semua metode dari 65,2\% dari tatal Pasangan Usia Subur (PUS) di tahun 2015 menjadi 66\% di tahun 2019, (4) menurunnya kebutuhan ber-KB tidak terlayani/unmet need dari $10,6 \%$ di tahun 2015 menjadi 9,91\% di tahun 2019, (5) menurunnya Age Spesific Fertility Rate (ASFR) dari 46 per 1000 perempuan kelompok umur 15 - 19 tahun di tahun 2015 menjadi 28 per 100 perempuan pada kelompok umur yang sama di tahun 2019, (6) menurunnnya persentase kehamilan yang tidak diinginkan dari WUS dari $7,1 \%$ di tahun 2015 menjadi 6,6\% di tahun 2019 (BKKBN, 2015).

Dalam pelaksanaanya, Kampung KB memerlukan dukungan seluruh perangkat pemerintah dan lebih lebih pihak swasta untuk bekerja sesuai dengan kebutuhan dan kondisi wilayah setempat, serta dilaksanakan di tingkat pemerintah terendah setingkat RT (BKKBN, 2017). Program kampung KB merupakan salah satu dari realisasi pemerintah untuk meningkatkan kualitas hidup masyarakat sesuai dengan indikator pencapaian program Kependudukan Keluarga Berencana dan Pembangunan Keluarga (KKBPK). Keberhasilan program Kependudukan Keluarga Berencana dan Pembangunan Keluarga (KKBPK) ini dapat dilihat dari 3 aspek: pertama, dari aspek pengendalian kuantitas penduduk, kedua, dari aspek peningkatan kualitas penduduk yang dalam hal ini diukur dengan peningkatan ketahanan dan kesejahteraan keluarganya. Peningkatan ketahanan dan kesejahteraan keluarga dapat ditelusur melalui berbagi indikator yang merupakan pencerminan dari pelaksanaan 8 fungsi keluarga sebagaimana tercantum dalam Peraturan Pemerintah No 87 Tahun 2014 tentang Perkembangan Kependudukan dan Pembangunan Keluarga, Keluarga Berencana dan Sistem Informasi Keluarga. Dalam Peraturan Pemerintah tersebut disebutkan bahwa 8 fungsi keluarga meliputi: (1) fungsi keagamaan, (2) fungsi sosial budaya, (3) fungsi cinta kasih, (4) fungsi perlindungan, (5) fungsi reproduksi, (6) fungsi sosialisasi dan pendidikan, (7) fungsi ekonomi dan (8) fungsi pembinaan lingkungan. Indikator tersebut kemudian diejawantahkan dalam berbagai capaian yang diukur dari peningkatan jumlah KB baru, terlayaninya kesehatan ibu hamil dan menyusui, remaja aktif dalam kegiatan Bina Keluarga Remaja (BKR) dan Pusat Informasi dan Konseling Kesehatan Reproduksi Remaja (PIK-R), perempuan yang buta aksara, meningkatnya partisipasi pra sejahtera dan KS-1 keluarga dalam Usaha Peningkatan Pendapatan Keluarga Sejahtera (UPPKS) (BKKBN, 2017).

Penentuan Kampung KB tentunya tidak terlepas dari kriteria yang telah dibuat oleh BKKBN, setidaknya ada beberapa kriteria untuk menentukan layak atau tidaknya sebuah daerah dijadikan Kampung KB antara lain; Jumlah Keluarga Pra Sejahtera dan KS 1 (miskin) di atas rata-rata Pra Sejahtera dan KS 1 tingkat desa/kelurahan di mana kampung tersebut berada. Serta jumlah peserta KB di bawah rata-rata pencapaian peserta $\mathrm{KB}$ tingkat desa/kelurahan dimana kampung tersebut berlokasi. Sedangkan kriteria wilayah dalam pembentukan Kampung KB mencakup 10 kategori wilayah (dipilih salah satu), yaitu: 1. Kumuh 2. Pesisir atau Nelayan 3. Daerah Aliran Sungai (DAS) 4. Bantaran Kereta Api 
5. Kawasan Miskin (termasuk Miskin Perkotaan) 6. Terpencil 7. Perbatasan 8. Kawasan Industri 9. Kawasan Wisata 10. Padat Penduduk. Untuk kriteria khusus pembentukan Kampung KB meliputi Kriteria data, dimana setiap RT/RW memiliki Data dan Peta Keluarga yang bersumber dari hasil Pendataan Keluarga, data Kependudukan dan atau pencacatan sipil yang akurat, serta kriteria kependudukan, dimana angka partisipasi penduduk usia sekolah rendah (BKKBN, 2015).

Tulisan ini nantinya akan menganalisa kontribusi program Kampung KB dalam upaya peningkatan Program KKBPK di Kabupaten Jombang Provinsi Jawa Timur. Mayoritas Kampung KB di Kabupaten Jombang merupakan daerah terpencil, berada di sekitaran hutan, perekonomian masyarakat banyak bergantung pada sektor pertanian maupun perkebunan serta akses pendidikan maupun kesehatan rendah. Terdapat 3 lokasi Kampung KB yang menjadi lokus dalam penelitian ini antara lain Dusun Munggut, Desa Cupak, Kecamatan Ngusikan; Dusun Pulonasir, Desa Pulosari, Kecamatan Bareng dan Dusun Sumberpelas, Desa Plabuhan, Kecamatan Wonosalam.

\section{METODE}

Penelitian ini menggunakan pendekatan kualitatif dengan metode penelitian studi eksploratif. Untuk memperoleh data, peneliti menggunakan instrumen berupa wawancara mendalam (indepth interview) dan observasi lapangan serta dianalisis dengan cara non statistik sesuai dengan sifat metode penelitian deskriptif dimana peneliti akan membuat deskripsi secara sistematis, faktual, dan akurat mengenai fakta dari Kampung KB di 3 Desa yakni Dusun Pulonasir, Desa Pulosari, Kec. Bareng; Dusun Munggut, Desa Cupak, Kec. Ngusikan; dan Dusun Sumberpelas Desa. Plabuhan, Kec. Plandaan. Penentuan lokasi tersebut didasarkan pada lokasi kampung KB di daerah terpencil, penduduk pra sejahtera cukup tinggi, tahun pencanangan 2016 dan 2017 serta akses pendidikan dan kesehatan yang minim. Keberadaan peneliti di tengah masyarakat Kampung KB tersebut, menjadikan peneliti memahami dan mendengar langsung percakapan dan cerita dari masyarakat, berbicara dengan mereka, melakukan wawancara, membaca pemberitaan media, serta memverifikasi data- data dan informasi pendahulu kepada stakeholder yang ada. Untuk mempermudah melihat hasil rangkuman, maka dibuat matriks. Dalam pola bentuk matriks tersebut dapat dilihat gambaran seluruhnya atas bagian-bagian tertentu dari hasil penelitian. Atas dasar pola yang tampak pada display data, ditarik kesimpulan sehingga data yang dikumpulkan memunyai makna, yang pada awalnya bersifat sangat tentatif atau kabur. Agar kesimpulan lebih grounded maka verifikasi dilakukan sepanjang penelitian. Hal ini dimaksudkan untuk menjamin tingkat kepercayaan hasil penelitian, sehingga prosesnya berlangsung sejalan dengan member check, triangulasi dan audit trail (Sugiyono, 2015: 21).

\section{HASIL DAN PEMBAHASAN}

\section{Kontribusi Program Kampung KB terhadap Upaya Peningkatan Program KKBPK di Kabupaten Jombang}

Berdasarkan data DPPKB Kabupaten
Jombang setidaknya hampir seluruh kecamatan di Kabupaten Jombang telah terdapat Kampung KB. Namun ada beberapa desa yang menjadi rintisan Kampung KB seperti Dusun Munggut, Desa Cupak, Kecamatan Ngusikan yang diresmikan pada tahun 2015. Kecamatan Ngusikan merupakan kecamatan pemekaran dari Kecamatan Kudu berdasarkan Peraturan Daerah Kabupaten Jombang Nomor 15 Tahun 2000. Sedangkan secara Geografis Kecamatan Ngusikan terletak di sebelah utara Sungai Brantas dan merupakan Kecamatan yang berbatasan langsung dengan Kabupaten Mojokerto dan Kabupaten Lamongan. Berdasarkan peta di bawah ini dapat kita ketahui bahwa Kecamatan Ngusikan yang diberi warna kuning muda merupakan Kecamatan yang letaknya di Timur Laut Kabupaten Jombang. Kecamatan Ngusikan terletak di $7^{\circ} 22^{\prime}$, $15^{\prime}$ " LS s/d $7^{\circ} 28^{\prime}$ '49" LS dan $112^{\circ} 16^{\prime} 21^{\prime \prime}$ BT s/d $112^{\circ} 21^{\prime}$ 56" BT. Kecamatan Ngusikan memiliki 11 wilayah desa antara lain Desa Asem Gede, Kromong, Cupak, Mojodanu Ngampel, Manunggal, Sumbernongko, Ngusikan, Kedung Bogo, Ketapang Kuning, dan Keboan. Berdasarkan jarak dengan ibukota kabupaten, Kecamatan Ngusikan merupakan kecamatan yang terjauh dengan jarak tempuh hingga $26 \mathrm{Km}$. Jauhnya pusat 
kegiatan mengakibatkan Kecamatan Ngusikan cenderung tertinggal dalam pembangunan fisik maupun sosial. Beberapa desa yang terletak di bagian utara kecamatan ngusikan cenderung tertinggal karena rendahnya aksesibilitas sehingga keterjangkauannya pun rendah.

Desa Cupak adalah salah satu desa yang terletak di bagian utara Kecamatan Ngusikan. Desa cupak berbatasan dengan Desa Asem Gede di sebelah utara, Desa Kromong di sebelah timur, Desa Made, Kecamatan Kudu di sebelah selatan dan Hutan di sebelah barat. Sebagian besar wilayah desa cupak merupakan hutan jati dengan relief perbukitan. Secara administratif Desa Cupak memiliki dua Dusun yaitu Dusun Cupak dan Dusun Munggut. Kedua Dusun terpisah oleh hutan dengan jarak sejauh $6 \mathrm{Km}$ dan belum ada akses jalan memadai yang menghubungkan kedua dusun tersebut. Dusun Cupak memiliki 4 RT dan Dusun Munggut juga memiliki 4 RT.

Dusun Munggut merupakan salah wilayah di Kabupaten Jombang yang terletak di Desa Cupak Kecamatan Ngusikan. Munggut merupakan salah satu wilayah di Jombang yang sulit dijangkau. Hal ini dikarenakan dusun Munggut berjarak $6 \mathrm{Km}$ dari Pusat Kegiatan desa (Balai Desa), $10 \mathrm{Km}$ dari Ibu Kota Kecamatan Ngusikan dan 30 $\mathrm{Km}$ dari Ibu Kota Kabupaten Jombang. Selain itu infrastruktur jalan menuju Dusun Munggut juga tidak memadai. Untuk dapat mencapai Dusun Munggut terdapat dua jalur jalan yang dapat ditempuh, jalur pertama melalui rute Ngusikan-Cupak-Munggut pada rute ini membutuhkan jarak tempuh $14 \mathrm{Km}$ dengan sebagian besar merupakan jalan batu. Jalur kedua bisa melalui Ngusikan-Made(Kudu)Munggut, apabila melalui jalur ini jarak tempuh hanya $10 \mathrm{Km}$ dengan jalan tanah dengan topografi yang cukup curam di beberapa titik sehingga sangat berbahaya untuk dilewati pada saat musim penghujan. Dengan melalui dua rute tersebut baik melewati Desa Cupak maupun Desa Made belum ada kendaraan umum yang mengakses Dusun Munggut.

Dusun Munggut memiliki luas wilayah sebesar 5,18 $\mathrm{Km} 2$ namun sebagian besar merupakan hutan. Dusun Munggut terletak pada ketinggian kurang dari $500 \mathrm{~m}$ tetapi memiliki kemiringan lereng $2-15 \%$.
Dengan kemiringan lereng tersebut serta jenis tanah karst menyebabkan tanaman jati mendominasi wilayah dusun munggut. Sebagian besar pola penggunaan lahan di Dusun Munggut yaitu wilayah hutan 60\%, Lahan Pertanian (tembakau, tebu dan padi) $20 \%$, Pemukiman warga $15 \%$ serta untuk fasilitas umum 5\%. Bangunan fasilitas umum di Dusun Munggut antara lain satu Masjid, dua Surau/Musholla, satu Sekolah Dasar Negeri, serta bangunan perumahan guru yang terbengkalai karena tidak dilanjutkan pembangunannya.

Balai Dusun dan Polindes belum terdapat di Dusun Munggut, sehingga untuk mendapatkan fasilitas kesehatan warga harus menempuh jarak yang cukup jauh ke Cupak ataupun Desa Lain yang dekat dengan dusun munggut. Tenaga medis hanya ada satu bidan desa yang berdomisili di Desa Cupak. Dengan digiatkannya imunisasi, posyandu, pemberantasan penyakit menular, UPGK, UKS, GSI, BKB dan sebagainya Bidan Desa harus menempuh jarak yang cukup jauh untuk mencapai dusun Munggut. Fasilitas dan sarana prasarana khususnya bidang kesehatan di Dusun Munggut bisa dikatakan tidak memadai, hal ini dikarenakan masih terbatasnya tenaga personil dan prasarana yang ada.

Kondisi jalan di Dusun Munggut sudah berupa aspal cor dan paving, akan tetapi itu hanya sepanjang wilayah pemukiman di Dusun Munggut. Jalan menuju Dusun Munggut yang ditempuh melalui Desa Cupak, dari Ibu Kota Kecamatan Ngusikan sudah beraspal namun dalam kondisi rusak sampai dengan Dusun Cupak, akses jalan dari Dusun Cupak menuju Dusun Munggut berupa jalan batu. Kondisi jalan menuju Dusun Munggut yang ditempuh melalui Desa Made berupa jalan tanah sehingga menjadi sangat rawan apabila musim hujan. Setiap rumah di Dusun Munggut sudah dapat menikmati aliran listrik dari PLN. Namun demikian listrik belum dapat dimanfaatkan secara maksimal dan pada umumnya hanya untuk lampu penerangan dan untuk kebutuhan rumah tangga lainnya seperti TV, kulkas dan sebagainya. Sedangkan kebutuhan air/air minum didapat dengan memanfaatkan sumber-sumber air dari pegunungan yang dialirkan melalui pipa-pipa paralon ke rumah-rumah warga. Akan tetapi debit air sangat kecil dan hanya dapat 
mengalir pada jam-jam tertentu saja. Rumahrumah penduduk sebagian besar berdinding kayu karena memang kayu jati mudah didapat. Masih banyak rumah warga yang berlantai tanah dikarenakan tanah di Dusun Munggut cenderung labil sehingga tanah mudah retak apabila di semen atau keramik. Untuk Komunikasi warga sudah dapat mengoperasikan Handphone meskipun hanya sinyal dari provider tertentu yang dapat masuk ke Dusun Munggut. Untuk Sanitasi/ persampahan di rumah-rumah penduduk telah terdapat jamban keluarga. Pengelolaan sampah masih dengan menggunakan sistem pembakaran karena masyarakat Desa Cupak belum mengenal sistem daur ulang sampah.

Pada tahun 2016, Pemerintah Kabupaten Jombang menetapkan Dusun Munggut, Desa Cupak, Kecamatan Ngusikan, sebagai Kampung Keluarga Berencana (KB). Pencanangan Kampung KB di Dusun Munggut dilakukan secara simbolik oleh Bupati Jombang Nyono Suharli Wihandoko bersama Wakil Bupati Mundjidah Wahab, Forum Koordinasi Pimpinan Daerah Kabupaten Jombang, serta Direktur Advokasi BKKBN Yunus Patriawan Noya. Penetapan lokasi Kampung KB di Dusun Munggut ini didasarkan pada kondisi daerah yang cukup terpencil, akses infrastruktur, pendidikan dan kesehatan yang minim. Pun, kesejahteraan ekonomi masyarakat yang masih membutuhkan perhatian. Dari sisi demografi, Dusun Munggut memiliki jumlah sebanyak 464 dengan rincian penduduk Laki-laki 225 Jiwa dan penduduk Perempuan 239 Jiwa. Seluruh penduduk terutama yang berusia di bawah 17 Tahun sudah memiliki akta kelahiran. Dalam setahun jumlah penduduk yang melangsungkan pernikahan yang tercatat di KUA Kecamatan Ngusikan hanya 2 orang, hal ini dikarenakan jumlah penduduk berusia muda jumlahnya lebih sedikit dibandingkan dengan penduduk yang berusia lanjut. Pasangan Usia Subur (PUS) yang ada di Dusun Munggut sejumlah 173. Sebagian besar PUS sedah berKB dengan menggunakan berbagai metode kontrasepsi. Lebih dari $50 \%$ PUS memilih menggunakan alokon suntik, 7 PUS memilih MOW, 7 PUS memilih alokon implant, 8 PUS memilih alokon Pil, dan 2 Pus menggunakan Kondom. Sebanyak 2,1\% PUS bukan peserta KB karena sedang hamil, 3\% PUS bukan peserta KB karena Ingin anak segera, 2,1\% PUS bukan peserta KB karena Ingin anak tunda, dan $7,4 \%$ PUS bukan peserta KB karena tidak ingin anak lagi.

Tabel 1 Penggunaan Kontrasepsi di Dusun Munggut, Desa Cupak tahun 2017

\begin{tabular}{clc} 
No & Kontrasepsi & Jumlah \\
1 & IUD & 0 \\
2 & MOW & 7 \\
3 & MOP & 0 \\
4 & Implant & 7 \\
5 & Suntik & 84 \\
6 & Pil & 2 \\
7 & Kondom & 0 \\
& Jumlah & 100 \\
\hline
\end{tabular}

Sumber PLKB

Sedangkan untuk, komposisi penduduk berdasarkan agama $100 \%$ penduduk di dusun munggut memeluk agama islam. tingkat pendidikan didominasi oleh penduduk dengan pendidikan terakhir lulus SMP. Berdasarkan mata pencaharian 195 penduduk Dusun Munggut berprofesi sebagai petani dengan rincian petani pemilik 40 orang, petani penggarap 78 orang dan 77 sebagai buruh tani. Petani tersebut menggarap lahan berupa sawah padi dan ladang tembakau. Sebagian besar petani juga merangkap sebagai peternak, 15 peternak sapi, 5 peternak kambing, dan 125 peternak ayam. Selain sebagai petani jenis mata pencaharian penduduk dusun munggut yaitu buruh bangunan, wiraswasta, dan pedagang, hanya terdapat satu penduduk yang berprofesi sebagai PNS/TNI/Polri.

Dari sisi program Bina ketahanan keluarga yang ada di Dusun Munggut terdiri dari satu kelompok Bina Keluarga Balita, satu kelompok Bina Keluarga Remaja, serta satu kelompok Bina Keluarga Lansia. Kader-kader dan sasaran keluarga balita, remaja, ataupun lansia di Dusun Munggut sudah ada. Tetapi struktur organisasinya belum terbentuk dengan baik. Selain itu di Dusun Munggut juga belum terdapat fasilitas/ sarana media pelatihan keluarga balita, remaja dan lansia seperti BKB Kit, BKR Kit, ataupun BKL Kit. Sarana prasarana berupa aula/balai juga belum ada untuk pelaksanaan kegiatan tribina ketahanan keluarga ini, sehingga untuk mengadakan kegiatan tersebut seringkali dilaksanankan di kediaman kader dengan jadwal yang tidak teratur. 
Budaya dan adat istiadat di Dusun Munggut sama seperti desa-desa lain yang ada di Kecamatan Ngusikan. adat istiadat Dusun Munggut mencerminkan adat Jawa, yang masih melekatnya adat selamatan, sesajen dan percaya pada roh-roh ghaib, walaupun sebagian telah memudar karena kemajuan pengetahuan dan teknologi. di Dusun Cupak yang letaknya tidak jauh dari Dusun Munggut terdapat tempat pemujaan dan pemberian sesajen yaitu Gunung pucangan, tempat ini dianggap sebagai tempat wisata religi sehingga setiap tanggal-tanggal tertentu gunung pucangan ini akan dipenuhi pengunjung. Mengenai budaya dapat disebutkan bahwa banyak/kaya akan khasanah budaya baik budaya Jawa seperti tayub, ludruk campur sari, kuda lumping, budaya Islam seperti qasidah, hadrah, dan robbana.

Keberadaan Kampung KB di Dusun Munggut sejak 2016 memang telah membawa dampak yang signifikan utamanya dalam hal pembangunan infrastruktur yang dananya bersumber dari APBN hingga APBD. Di sisi lain, terdapat pula bantuan- bantuan bagi kelompok tani yang ada di Dusun Munggut, Desa Cupak, Kecamatan Ngusikan tersebut.

Tabel 2 Data Program Kegiatan Pasca Pencanangan Kampung KB di Dusun Munggut

\begin{tabular}{|c|c|c|c|}
\hline No & Program & Tahun & $\begin{array}{c}\text { Sumber } \\
\text { Anggaran }\end{array}$ \\
\hline 1 & $\begin{array}{l}\text { Pembinaan dan } \\
\text { Penyuluhan KB } \\
\text { dan Tribina, } \\
\text { PIKR, UPPKS } \\
\text { oleh DPPKB } \\
\text { Kabupaten } \\
\text { Jombang } \\
\end{array}$ & 2017 & APBD \\
\hline 2 & $\begin{array}{l}\text { Baksos oleh } \\
\text { Dinas Kesehatan }\end{array}$ & 2016 & APBD \\
\hline 3 & $\begin{array}{l}\text { Penyerahan } \\
\text { BKL Kit, BKB } \\
\text { Kit dan Genre } \\
\text { Kit }\end{array}$ & 2017 & APBD \\
\hline 4 & $\begin{array}{l}\text { Penyerahan } \\
\text { Bantuan Ternak } \\
10 \text { Kambing } \\
\text { Jantan dan } 20 \\
\text { Kambing Betina }\end{array}$ & 2017 & APBD \\
\hline 5 & $\begin{array}{l}\text { Pelatihan CTU } \\
\text { Bidan }\end{array}$ & 2016 & $\begin{array}{c}\text { APBD } \\
\text { (BKKBN } \\
\text { Provinsi Jawa } \\
\text { Timur) } \\
\end{array}$ \\
\hline 6 & Obgyn Bed, & 2016 & APBD \\
\hline
\end{tabular}

\begin{tabular}{clcc}
\hline & $\begin{array}{l}\text { Implan Kit, IUD } \\
\text { Kit dan Leaflet }\end{array}$ & $\begin{array}{c}\text { (BKKBN } \\
\text { Provinsi Jawa } \\
\text { Timur) }\end{array}$ \\
\hline 7 & $\begin{array}{l}\text { Kartu KB } \\
\text { Informed } \\
\text { Consent }\end{array}$ & 2016 & $\begin{array}{c}\text { APBD } \\
\text { (BKKBN } \\
\text { Provinsi Jawa } \\
\text { Timur) }\end{array}$ \\
\hline 8 & Jalan Cor & 2017 & $\begin{array}{c}\text { APBD } \\
\text { (Dinas PUPR } \\
\text { Kabupaten } \\
\text { Jombang }\end{array}$ \\
\hline 9 & $\begin{array}{l}\text { Penerangan } \\
\text { Jalan Umum }\end{array}$ & 2017 & $\begin{array}{c}\text { APBD } \\
\text { (Dinas PUPR } \\
\text { Kabupaten } \\
\text { Jombang }\end{array}$ \\
\hline 10 & Jalan Cor & 2016 & $\begin{array}{c}\text { APBN } \\
\text { (Kemendes } \\
\text { PDT) }\end{array}$ \\
\hline
\end{tabular}

Sumber: PLKB

Selain Dusun Munggut, Desa Cupak, Kecamatan Ngusikan, wilayah lain yang ditetapkan sebagai Kampung KB di Kabupaten Jombang adalah Dusun Sumberpelas, Desa Plabuhan, Kecamatan Plandaan. Pencanangan Kampung KB di dusun tersebut dilaksanakan pada tahun 2016 setelah pencanangan di Dusun Munggut. Dusun Sumberpelas merupakan salah satu dusun yang terletak di bagian utara Desa Plabuhan, Kecamatan Plandaan. Secara administratif terdiri dari 3 RT dengan luas wilayah 5,18 $\mathrm{Km} 2$. Sebagian besar wilayahnya merupakan pemukiman penduduk dan hutan dengan relief perbukitan. Dusun Sumberpelas terletak pada ketinggian kurang dari $500 \mathrm{~m}$ tetapi memiliki kemiringan lereng $2-15 \%$. Dengan kemiringan lereng tersebut serta jenis tanah karst menyebabkan tanaman jati mendominasi wilayah dusun Sumberpelas. Secara geografis, Dusun Sumberpelas berbatasan dengan Dusun Kalirejo, Desa Darurejo di sebelah utara, Dusun Bangsri, Desa Bangsri di sebelah timur, Dusun Plabuhan, Desa Plabuhan di sebelah selatan dan Dusun Gembyang, Desa Plabuhan di sebelah barat. Dusun Sumberpelas merupakan salah satu dusun dengan aksesibilitas yang sulit dijangkau. Hal ini dikarenakan Dusun Sumberpelas berjarak $1,5 \mathrm{Km}$ dari Pusat kegiatan desa (Balai Desa) dengan jalur yang cukup sulit. Infrastruktur jalan menuju Dusun Sumberpelas juga tidak memadai. Untuk dapat mencapai Dusun Sumberpelas terdapat dua jalur jalan yang dapat ditempuh, jalur 
pertama melalui rute Bangsri - Jambe Sumberpelas pada rute ini sebagian besar merupakan jalan beraspal yang rusak parah. Jalur kedua bisa melalui Bangsri - Plabuhan Sumberpelas, apabila melalui jalur ini jalan yang dilalui sebagian besar tanah dengan topografi yang cukup curam di beberapa titik sehingga sangat berbahaya untuk dilewati pada saat musim penghujan. Dengan melalui dua rute tersebut baik melewati Desa Bangsri maupun Desa Plabuhan belum ada kendaraan umum yang mengakses Dusun Sumberpelas.

Selain itu, Kondisi rumah-rumah penduduk di Dusun Sumberpelas sebagian besar berdinding kayu karena memang kayu jati mudah didapat. Masih banyak rumah warga yang berlantai tanah dikarenakan tanah di Dusun Sumberpelas cenderung labil sehingga tanah mudah retak apabila di semen atau keramik. Untuk Komunikasi warga sudah dapat mengoperasikan Handphone meskipun hanya sinyal dari provider tertentu yang dapat masuk ke Dusun Sumberpelas. Untuk Sanitasi/ persampahan di rumah-rumah penduduk telah terdapat jamban keluarga. Pengelolaan sampah masih dengan menggunakan sistem pembakaran karena masyarakat Desa Plabuhan belum mengenal sistem daur ulang sampah. Kondisi jalan di sepanjang wilayah pemukiman Dusun Sumberpelas sudah berupa paving, sedangkan Jalan menuju Dusun Sumberpelas yang ditempuh melalui Desa Bangsri, dari Ibu Kota Kecamatan Plandaan sudah beraspal namun dalam kondisi rusak parah. Kondisi jalan menuju Dusun Sumnerpelas yang ditempuh melalui Desa Plabuhan berupa jalan berbatu dengan kemiringan curam sehingga sangat rawan dilewati, terutama apabila musim hujan. Setiap rumah di Dusun Sumberpelas sudah dapat menikmati aliran listrik dari PLN dan pada umumnya dimanfaatkan untuk lampu penerangan dan untuk kebutuhan rumah tangga lainnya. Sedangkan kebutuhan air/air minum didapat dengan memanfaatkan air sumur yang dialirkan ke rumah warga dengan menggunakan pompa air, air PAM dan air sumber yang diperoleh dengan cara menimba.

Di sisi demografi, Di Dusun sumberpelas terdapat $104 \mathrm{KK}$ dengan jumlah penduduk 327 jiwa terdiri dari laki-laki 167 jiwa dan perempuan 160 jiwa. Penduduk terutama yang berusia di bawah 17 tahun sebagian besar sudah memiliki akta kelahiran. Jumlah penduduk yang melangsungkan pernikahan yang tercatat di KUA Kecamatan Plandaan pada tahun 2015 sebanyak 5 orang, sedangkan tahun 2016 belum ada pernikahan yang tercatat. Pasangan Usia Subur (PUS) yang ada di Dusun Sumberpelas sejumlah 58. Sebagian besar PUS sedah ber KB dengan menggunakan berbagai metode kontrasepsi. Selain itu, tingkat pendidikan berpengaruh pada kualitas sumberdaya manusia. Proses pembangunan akan berjalan dengan lancar apabila masyarakat memiliki tingkat pendidikan yang cukup tinggi. Data penduduk Dusun Sumberpelas menurut tingkat pendidikannya dapat dilihat pada Tabel berikut:

Tabel 3 Data Tingkat Pendidikan Masyarakat Dusun Sumberpelas, Desa Plabuhan

\begin{tabular}{clc}
\hline No. & \multicolumn{1}{c}{ Tingkat Pendidikan } & $\begin{array}{c}\text { Jumlah } \\
\text { (Orang) }\end{array}$ \\
\hline 1 & Tidak Sekolah / Buta Huruf & 49 \\
\hline 2 & Tidak Tamat SD/Sederajat & 19 \\
\hline 3 & Tamat SD / sederajat & 139 \\
\hline 4 & Tamat SLTP / sederajat & 71 \\
\hline 5 & Tamat SLTA / sederajat & 46 \\
\hline 6 & Tamat D1, D2, D3 & 0 \\
\hline 7 & Sarjana / S-1 & 3 \\
\hline
\end{tabular}

Sumber Data : Data Potensi Sosial Ekonomi Desa/Kelurahan Tahun 2015

Ditinjau dari segi agama dan kepercayaan masyarakat Dusun Sumberpelas keseluruhan beragama Islam. Sedangkan mata pencaharian penduduk di Dusun Sumberpelas sebagian besar masih berada di sektor pertanian. Hal ini menunjukkan bahwa sektor pertanian memegang peranan penting dalam bidang ekonomi masyarakat. Data menurut mata pencaharian penduduk dapat dilihat pada Tabel berikut ini:

Tabel 4 Data Mata Pencaharian Masyarakat

\begin{tabular}{clc}
\multicolumn{2}{c}{ Dusun Sumberpelas, Desa Plabuhan } \\
\hline No. & Jenis Pekerjaan & $\begin{array}{c}\text { Jumlah } \\
\text { (Orang) }\end{array}$ \\
1 & Tani & 130 \\
2 & Buruh Tani & 25 \\
3 & Dagang & 9 \\
4 & Supir & 1 \\
5 & PNS & - \\
6 & TNI & - \\
7 & Polri & 2 \\
\hline
\end{tabular}

Sumber Data : Data Potensi Sosial Ekonomi Desa/Kelurahan Tahun 2015 
Mayoritas mata pencarian penduduk Desa Plabuhan bergerak dibidang pertanian. Permasalahan yang sering muncul berkaitan dengan mata pencaharian penduduk adalah tersedianya lapangan pekerjaan yang kurang memadai dengan perkembangan penduduk sebagaimana tertuang dalam perencanaan pembangunan daerah Kabupaten Jombang. Hal lain yang perlu diperhatikan dalam pembangunan desa adalah melakukan usaha perluasan kesempatan kerja dengan melakukan penguatan usaha kecil pemberian kredit sebagai modal untuk pengembangan usaha khususnya di bidang perdagangan. Diharapkan kedepannya masyarakat Desa Plabuhan terutama masyarakat Dusun Sumberpelas bisa mencari peluang lain yang bisa menunjang peningkatan taraf ekonomi bagi masyarakat. Banyaknya kegiatan Ormas di Desa Plabuhan. seperti Remaja Masjid, Karang Taruna, Jamiyah Yasin, Tahlil, PKK, Posyandu, Kelompok Arisan merupakan aset desa yang bermanfaat untuk dijadikan media penyampaian informasi dalam setiap proses pembangunan desa pada masyarakat.

Setelah dicanangkannya Kampung KB di Dusun Sumberpelas pada tahun 2016, penggunaan akseptor KB di dusun tersebut mengalami perubahan yang signifikan. Pilihan Alkon yang digunakan antara lain 38 PUS memilih KB suntik, 10 PUS memilih KB implant, dan 7 PUS memilih KB Pil, dan Tidak ada PUS menggunakan KB IUD maupun MOW. Sedangkan partisipasi KB Pria MOP dan Kondom belum ada. Sebanyak 1 PUS bukan peserta KB karena sedang hamil, dan 2 orang PUS bukan peserta KB karena ingin anak segera.

Tabel 5 Penggunaan Kontrasepsi di Dusun Sumberpelas, Desa Plabuhan tahun 2017

\begin{tabular}{ccc}
\hline No & Kontrasepsi & Jumlah \\
\hline 1 & IUD & 0 \\
\hline 2 & MOW & 0 \\
\hline 3 & MOP & 0 \\
\hline 4 & Implan & 10 \\
\hline 5 & Suntik & 38 \\
\hline 6 & Pil & 7 \\
\hline 7 & Kondom & 0 \\
\hline & Jumlah & 55 \\
\hline
\end{tabular}

Sumber Data : PLKB
Pada program Bina ketahanan keluarga yang ada di Dusun Sumberpelas terdiri dari satu kelompok Bina Keluarga Balita, sedangkan kelompok Bina Keluarga Remaja, serta kelompok Bina Keluarga Lansia belum ada. Selain itu di Dusun Sumberpelas juga belum terdapat fasilitas/ sarana media pelatihan keluarga balita (BKB Kit) sudah ada, sedangkan media pelatihan remaja dan lansia BKR Kit, ataupun BKL Kit belum ada. Sarana prasarana berupa aula/balai untuk pelaksanaan kegiatan tribina ketahanan keluarga ini dilaksanankan di balai Dusun Sumberplas.

Tabel 6 Jumlah Sasaran Program Ketahanan Keluarga di Dusun Sumberpelas

\begin{tabular}{cclc}
\hline No & $\begin{array}{c}\text { Kelompok } \\
\text { Umur }\end{array}$ & $\begin{array}{l}\text { Sasaran } \\
\text { Program }\end{array}$ & Jumlah \\
\hline 1 & $<1$ Tahun & Bayi & 4 \\
\hline 2 & $1-4$ Tahun & Balita & 13 \\
\hline 3 & $5-6$ Tahun & Kemas & 9 \\
\hline 4 & $\begin{array}{c}7-14 \\
\text { Tahun }\end{array}$ & $\begin{array}{l}\text { Remaja } \\
\text { Muda }\end{array}$ & 52 \\
\hline 5 & $\begin{array}{c}15- \\
24 \text { Tahun }\end{array}$ & $\begin{array}{l}\text { Remaja } \\
\text { Dewasa }\end{array}$ & 25 \\
\hline 6 & $\begin{array}{c}25-65 \\
\text { Tahun }\end{array}$ & Produktif & 197 \\
\hline 7 & $>65$ Tahun & Lansia & 27 \\
\hline \multicolumn{5}{c}{ Jumlah } & 327 \\
\hline
\end{tabular}

Di Kabupaten Jombang, selain Dusun Munggut dan Dusun Sumberpelas, Kampung KB yang dicanangkan pada tahun 2016 adalah Dusun Pulonasir, Desa Pulosari, Kecamatan Bareng. Desa Pulosari merupakan Desa yang terletak $\pm 8 \mathrm{Km}$ dari pusat Pemerintahan Kecamatan Bareng Secara administratif batasbatas Desa Pulosari adalah sebagai berikut: Sebelah Utara: Desa Ngrimbi Kec. Bareng; Sebelah Selatan: Desa Jenis Gelaran Kec. Bareng; Sebelah Barat: Desa Nglebak Kec. Bareng dan Sebelah Timur: Desa Wonosalam Kec. Wonosalam. Desa Pulosari terdiri dari 3 Dusun 8 RW (Rukun Warga) dan 23 RT (Rukun Tetangga). Perincian Dusun tersebut adalah sebagai berikut: Dusun Sumber mulyo: 6 RT dan 2 RW; Dusun Pulosari: 9 RT dan 3 RW serta Dusun Pulonasir: 8 RT dan 3 RW.

Dusun Pulonasir merupakan salah satu dusun yang cukup terpencil di Desa Pulosari, Kecamatan Bareng. Akses menuju dusun tersebut sangat sulit, karena harus 
melalui hutan dan jalanan yang tak beraspal. Secara demografi, Dusun Pulonasir terdapat 496 KK yang terdiri dari Perempuan sejumlah 71 dan Laki- Laki sejumlah 425. Sedangkan jumlah penduduk sebesar 1.430 jiwa dengan rincian sebagai berikut:

Tabel 7 Data Jumlah Penduduk Dusun Pulonasir, Desa Pulosari, Kecamatan Bareng

\begin{tabular}{cc}
\hline Jenis Kelamin & Jumlah \\
\hline Laki- Laki & 712 Jiwa \\
\hline Perempuan & 718 Jiwa \\
\hline Jumlah & 1.430 Jiwa \\
\hline Sumber Data $\cdot$ PLKB
\end{tabular}

Salah satu aspek penting kesejahteraan di tingkat pedesaan adalah kondisi sumber daya manusia. Di Dusun Pulonasir, mayoritas masyarakat tamat pendidikan SD dan SMP sejumlah $258 \mathrm{KK}$; Tidak Tamat SD sebanyak $181 \mathrm{KK}$; Tamat SMA sebanyak $38 \mathrm{KK}$ dan Tamat Akademi sebanyak 8 KK. Sedangkan Pada aspek perekonomian, mayoritas masyarakat Dusun Pulonasir bermata pencaharian sebagai Buruh Tani, Petani dan Pedagang. Selain itu, mayoritas masyarakat Dusun Pulonasir juga termasuk Keluarga Pra Sejahtera dengan rincian data sebagai berikut:

Tabel 8 Data Jumlah Penduduk Prasejahtera dan KS di Dusun Pulonasir, Desa Pulosari, Kecamatan Bareng

\begin{tabular}{cc}
\hline $\begin{array}{c}\text { Kategori } \\
\text { Keluarga }\end{array}$ & Jumlah \\
\hline Pra-Sejahtera & 355 \\
\hline KS- 1 & 55 \\
\hline KS- 2 & 39 \\
\hline KS- 3 & 37 \\
\hline KS- 3+ & 10 \\
\hline
\end{tabular}

Sumber Data : PLKB

Setelah dicanangkannya Kampung KB di Dusun Pulonasir pada tahun 2016, penggunaan akseptor KB di dusun tersebut mengalami perubahan yang signifikan. Pilihan Alkon yang digunakan antara lain 71 PUS memilih KB suntik, 6 PUS memilih KB implant, dan 75 PUS memilih KB Pil, 39 menggunakan KB IUD dan 14 menggunakan KB MOW.
Tabel 5 Penggunaan Kontrasepsi di Dusun Pulonasir, Desa Pulosari tahun 2017

\begin{tabular}{ccc}
\hline No & Kontrasepsi & Jumlah \\
\hline 1 & IUD & 39 \\
\hline 2 & MOW & 14 \\
\hline 3 & MOP & 5 \\
\hline 4 & Implan & 6 \\
\hline 5 & Suntik & 71 \\
\hline 6 & Pil & 75 \\
\hline 7 & Kondom & 6 \\
\hline & Jumlah & 233 \\
\hline
\end{tabular}

Sumber Data : PLKB

Beberapa kegiatan Bina Ketahanan Keluarga juga sudah terpenuhi dan tingkat partisipasi masyarakat didalamnya cukup tinggi seperti Bina Keluarga Balita, Bina Keluarga Remaja, serta kelompok Bina Keluarga Lansia. Namun problemnya masih ada beberapa fasilitas pendukung yang belum terpenuhi. Begitupula program UPPKS juga belum tersedia secara maksimal, dikarenakan effort dari masyarakat masih cukup rendah dalam kegiatan yang ada.

Dari hasil penelitian di 3 lokasi kampung $\mathrm{KB}$ tersebut, dapat disimpulkan bahwa keberadaan kampung KB cukup berkontribusi pada beberapa indikator Program KKBPK seperti peningkatan angka pengguna akseptor KB baru yang mayoritas terjadi di seluruh lokasi Kampung KB. Selain itu, juga terlayaninya dengan baik kesehatan ibu hamil dan menyusui yang ditandai dengan tidak adanya lagi angka kematian terhadap ibu dan bayi di 3 lokasi tersebut. Pun, remaja aktif dalam kegiatan BKR dan PIK di setiap program yang ada dan menurunannya angka buta aksara. Namun ada salah satu indikator yang belum mengalami perubahan secara signifikan meski implementasi kampung KB berjalan hampir 2 tahun yakni belum maksimalnya program-program UPPKS di 3 lokasi kampung KB tersebut akibat tidak adanya modal untuk UPPKS, minimnya pengetahuan untuk menciptakan program serta rendahnya kesadaran maupun partisipasi masyarakat dalam program UPPKS.

\section{Faktor Pendukung Keberhasilan Implementasi Program Kampung KB di Kabupaten Jombang}

Sebagai sebuah proses, indikator ketercapaian model kampung KB tidak 
semata-mata hanya melihat hasil, namun keberhasilan juga didasarkan pada input, proses dan output. Keberhasilan input ditandai dengan jumlah PLKB/ PKB proporsional, kuantitas dan kualitas IMP, ketersediaan dukungan operasional (anggaran) untuk program KKBPK daari APBD dan APBN maupun sumber dana lain seperti PNPM, Anggaran Dana Desa (ADD), ketersediaan alat dan alat kontrasepsi, Jamkesda, maupun sarana pendukung lainnya. Sedangkan, Indikator Keberhasilan Proses dalam ketercapaian kampung KB ditentukan oleh Peningkatan frekuensi dan kualitas kegiatan advokasi dan KIE; Peningkatan kualitas pelayanan KB dan KR serta Pertemuan berkala kelompok kegiatan BKB, BKR, BKL, UPPKS dan pertemuan dalam mekop; Pelayanan Taman Posyandu, akta kelahiran. Sedangkan keberhasilan Output ditentukan terdiri dari indikator utama dan indikator penyerta/ pendukung.

1. Indikator Utama Kampung KB yaitu :

1) Meningkatnya persentasi peserta $\mathrm{Kb}$ aktif (PA) $65 \%$ dalam 3 Tahun s/d Tahun 2019.

2) Meningkatnya persentasi kesertaan $\mathrm{KB}$ MKJP menjadi 20\%

3) Unmet need $<10 \%$.

4) Terbinanya Pusmupar dan Pospartum dalam keberlangsungan pemakaian alat kontrasepesi.

5) Semua Ibu hamil, Ibu menyusui terlayani kesehatan dan KB

6) Semua keluarga yang punya anak $0-6$ Tahun terlayani BKB

7) Semua remaja dapat aktif dalam BKR dan PIK Remaja.

8) Meningkatkannya partisipasi keluarga dalam kegiatan BKB,/BKR / BKL/ UPPKS ( melalui lembaga keuangan mikro : koperasi \& per-bankan / BPR).

9) Kelompok lansia terlayani dalam BKL / Posbindu.

10) Semua anak usia $0-6$ Tahun terlayani dalam Taman Posyandu.

2. Indikator Penyerta / Pendukung Kampung KB yaitu :

1) Semua anak $(0-18$ th $)$ mendapatkan akta kelahiran.

2) Semua penduduk usia $\geq 17$ Tahun mempunyai KTP.

3) Terbinanya lingkungan/ Kampung dengan semua keluarga yang berprilaku hidup bersih dan sehat (PHBS), semua keluarga Renta mendapat bantuan dan penanganan sosial, serta tidak ditemukan rumah tidak layak huni, melalui PKLK \& KESLING (Kesehatan Lingkungan).

4) Semua anak usia 7 - 12 Tahun dan 13 15 Tahun bersekolah (Wajib Belajar Pendidikan Dasar).

5) Semua Penduduk bisa baca tulis.

6) KDRT nihil (tidak ada yang menjadi korban trafficking dan korban kekerasan dalam rumah tangga).

7) Jumlah pengangguran turun.

Untuk mencapai Keberhasilan kampung KB setidaknya terdapat 5 faktor utama, antara lain :

1. Komitmen yang kuat dari pemangku kebijakan disemua tingkatan (Kabupaten / Kota, Kecamatan, Desa/ kelurahan)

Salah satu hal paling mendasar dari keberhasilan kampung KB adalah political will atau komitmen dari kepala daerah atau pemangku kebijakan disemua tingkatan. Komitmen ini harus jelas agar setiap program dalam Kampung KB dapat berjalan baik dengan dukungan anggaran. Selain itu, komitmen ini diperlukan untuk menjembatani berbagai sektor yang harus mengambil bagian dari implementasi program Kampung KB tersebut. Pasalnya, implementasi program Kampung KB ini tidak dilakukan sendiri oleh OPD terkait KB melainkan diperlukan sinergi dari berbagai OPD yang ada.

2. Integrasi program KKBPK dan integrasi lintas sektor

Pada prinsipnya Program KKBPK mewujudkan keluarga kecil bahagia sejahtera dengan melaksanakan delapan fungsi keluarga. Penerapan fungsi keluarga ini membantu keluarga lebih bahagia dan sejahtera, terbebas dari kemiskinan, kebodohan dan keterbelakangan. Keberadaan Kampung KB selain membangun masyarakat berbasis keluarga, menyejahterakan masyarakat, serta memenuhi kebutuhan masyarakat melalui pelaksanaan integrasi program lintas sektor. Pembangunan lintas sektor dan kemitraan melibatkan peran bernagai pihak seperti swasta, provider, dan pemangku kepentingan lainnya. Integrasi lintas sektor 
berupa pelayanan terpadu antar sektor yang menjadi kebutuhan masyarakat, seperti pelayanan $\mathrm{KB}$, pelayanan pembuatan akta, pembangungan jalan dan jembatan, pembuatan ktp, pendiaan buku-buku bacaan, posyandu, PAUD, P2WKSS dan lain-lain.

3. Optimalisasi fasilitasi dan dukungan mitra/ stakeholder

Keberhasilan Kampung KB disamping meningkatkan peran pemerintah, lembaga non pemerintah dan swasta dalam memfasilitasi, melakukan pendampingan dan pembinaan kepada masyarakat agar turut berperan serta aktif dalam program pembangunan.

4. Semangat dan dedikasi para pengelola program KKBPK di lini lapangan (PKB, IMP)

Keberhasilan Program Kampung KB penting didukung adanya peningkatan kepedulian dan peran serta masyarakat dalam mengelola Program KB yang dilakukan oleh Instituasi Masyarakat Pedesaan (IMP), LSOM, swasta, tokoh masyarakat dan Institusi pemerintah yang terkait lainnya. Dalam upaya penguatan program tersebut, maka IMP bersama-sama PKB/PLKB senantiasa ikut serta dalam kegiatan kelompok seperti Bina-bina keluarga (BKB, BKR, BKL, PIK-R dan UPPKS) serta kegiatan lain yang berada di tingkat Desa ke bawah, seperti kelompok kerja teknis (Pokjanis) KB-Kesehatan, Pendidikan dan Penerangan serta Ekonomi produktif yang ada di Desa, yaitu pada Lembaga Pembangunan Masyarakat Desa (LPMD), disamping itu juga dengan PKK Desa/Dusun terutama pada pokja IV PKK yang membidangi masalah $\mathrm{KB}$ dan Kesehatan

5. Partispasi aktif masyarakat

Dukungan partisipasi aktif dari tokoh masyarakat, tokoh agama dan tokoh adat serta masyarakat dalam pengelolaan dan pelaksanaan seluruh kegiatan yang akan dilakukan di kampung KB secara berkesinambungan merupakan prasyarat pembentukan kampung $\mathrm{KB}$ guna meningkatkan taraf hidup seluruh masyarakat yang di wilayahnya. Selain itu keterlibatan pihak swasta dalam penggarapan program Pembangunan di Kampung KB sangat penting sebagai bentuk gotong royong dari semua pihak.

\section{KESIMPULAN DAN SARAN}

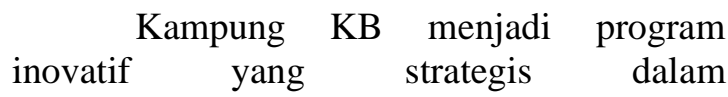
mengejawantahkan program KKBPK secara paripurna di lapangan. Pasalnya, Kampung KB menjadi model atau miniatur pembangunan yang melibatkan seluruh sektor di masyarakat. Kehadiran Kampung KB bertujuan meningkatkan kualitas hidup masyarakat di tingkat kampung atau yang setara melalui program KKBPK serta pembangunan sektor lain dalam rangka mewujudkan keluarga kecil berkualitas. Prinsipnya Program KKBPK mewujudkan keluarga kecil bahagia sejahtera dengan melaksanakan delapan fungsi keluarga. Penerapan fungsi keluarga ini membantu keluarga lebih bahagia dan sejahtera, terbebas dari kemiskinan, kebodohan dan keterbelakangan. Indikator keberhasilan Kampung KB terhadap program KKBPK meliputi peningkatan jumlah akseptor $\mathrm{KB}$ baru, terlayaninya kesehatan ibu hamil dan menyusui, remaja aktif dalam kegiatan BKR dan PIK, penurunan angka buta aksara, meningkatnya partisipasi keluarga pra sejahtera dan KS-1 dalam program UPPKS. Hasil penelitian di 3 lokasi kampung KB di Kabupaten Jombang yakni Dusun Munggut, Desa Cupak, Kecamatan Ngusikan; Dusun Sumberpelas, Desa Plabuhan, Kecamatan Plandaan dan Dusun Pulonasir, Desa Pulosari, Kecamatan Bareng, dapat disimpulkan bahwa keberadaan kampung KB sejak dicanangkan tahun 2016 cukup berkontribusi pada beberapa indikator Program KKBPK seperti peningkatan angka pengguna akseptor $\mathrm{KB}$ baru yang mayoritas terjadi di seluruh lokasi Kampung KB. Selain itu, juga terlayaninya dengan baik kesehatan ibu hamil dan menyusui yang ditandai dengan tidak adanya lagi angka kematian terhadap ibu dan bayi di 3 lokasi tersebut. Pun, remaja aktif dalam kegiatan BKR dan PIK di setiap program yang ada dan menurunannya angka buta aksara. Namun ada salah satu indikator yang belum mengalami perubahan secara signifikan meski implementasi kampung $\mathrm{KB}$ berjalan hampir 2 tahun yakni belum maksimalnya program-program UPPKS di 3 lokasi kampung KB tersebut akibat tidak adanya modal untuk UPPKS, minimnya pengetahuan untuk menciptakan program serta rendahnya 
kesadaran maupun partisipasi masyarakat dalam program UPPKS.

Namun untuk menyempurnakan implementasi program Kampung KB tersebut, yang paling utama adalah dibutuhkan komitmen atau political will para pengambil kebijakan di berbagai tingkatan mulai dari Pemerintah Daerah hingga Pemerintah Desa guna memberi dukungan total bagi setiap program yang direncanakan. Selain itu, menghilangkan ego sektoral menjadi kunci penting bagi keberhasilan program Kampung $\mathrm{KB}$, pasalnya implementasi program ini tidak semata mata menjadi tanggung jawab OPD terkait Kependudukan dan $\mathrm{KB}$ melainkan OPD lain yang terkait dengan Kesehatan, Pendidikan, Ekonomi, Pemberdayaan Masyarakat hingga penyediaan infrastruktur. Pembangunan lintas sektor dan kemitraan tersebut melibatkan peran berbagai pihak seperti swasta, provider dan pemangku kepentingan lainnya.

\section{DAFTAR PUSTAKA}

Badan Kependudukan Keluarga Berencana Nasional, 2015. Petunjuk Teknis Kampung KB. Jakarta: BKKBN

Mardiyono, 2017. Kampung KB sebagai Upaya Pemberdayaan Masyarakat / Keluarga di Jawa Timur. Jurnal Cakrawala Vol. 11 No. 2 Desember 2017: p 129-136

Prijono Onny S., \& A.M. W. Pranaka, 1996. Pemberdayaan: Konsep, Kebijakan dan Implementasi. Jakarta: Center for Strategic and International Studies.

Sugiyono. 2015. Metode Penelitian Kuantitatif, Kualitatif dan R \& D. Bandung: Alfabeta.

Zultha, Nurhafifah. 2017. Implementasi Program Kampung KB dalam Upaya Penanggulangan Kemiskinan. Lampung: Universitas Lampung

Kampung KB wujud Konkret People Centered Devolepment, Majalah Warta Kencana Edisi 12 halaman 89 Tahun IV /April 2013.

Profil Kampung KB Dusun Munggut, Desa Cupak, Kecamatan Ngusikan, Kabupaten Jombang

Profil Kampung KB Dusun Sumberpelas, Desa Plabuhan, Kecamatan Plandaan, Kabupaten Jombang
Profil Kampung KB Dusun Pulonasir, Desa Pulosari, Kecamatan Bareng, Kabupaten Jombang

Sensus Penduduk Tahun 2010 Badan Pusat Statistik

Undang-undang No. 52 tahun 2009 tentang Perkembangan Kependudukan dan Pembangunan Keluarga. Pasal 3 ayat (a) \& (b) 